\title{
In-hospital Outcomes of Patients with Cardiogenic Shock due to ST-Segment Elevation Myocardial Infarction
}

\author{
Francisco Hedilberto Feitosa Filho', Fabio Conejo르. Luciano Nunes dos Santos ${ }^{3}$, \\ Carlos Augusto Campos ${ }^{4}$, Pedro Alves Lemos Neto ${ }^{5}$
}

\begin{abstract}
Background: Cardiogenic shock is a clinical condition of inadequate tissue perfusion due to cardiac dysfunction. The most common etiology is ST-segment elevation myocardial infarction (STEMI) leading to left ventricular failure, but it may also be caused by mechanical complications such as acute mitral regurgitation, ventricular septal rupture or rupture of the left ventricular free wall. Despite therapeutic advances, mortality rates remain high. Methods: Retrospective, observational, single-center study, including consecutive patients admitted with a diagnosis of STEMI and cardiogenic shock treated by percutaneous coronary intervention $(\mathrm{PCl})$ at a tertiary hospital specialized in cardiology. The primary objective was to evaluate in-hospital clinical outcomes. Results: A total of 78 patients were included, most of them were male $(67.9 \%)$, mean age was $67.5 \pm 13,4$ years and $41.0 \%$ were diabetic. Primary PCI was performed in $46.2 \%$ of the patients, rescue $\mathrm{PCl}$ in $25.6 \%$ and elective $\mathrm{PCl}$ in $28.2 \%$ of the cases. The most frequently involved arteries were the left anterior descending artery and the right coronary artery, with $44.9 \%$ each. Intra-aortic balloon pump was used in $32.1 \%$ of cases and glycoprotein Ilb/ Illa inhibitors in $30.8 \%$ of the cases. The incidence of acute renal failure was $61.5 \%$. The need for reintervention was observed in $9.0 \%$ and the rate of acute/subacute thrombosis was $3.8 \%$. Death due to cardiogenic shock was observed in $46.2 \%$. Conclusions: Cardiogenic shock remains a frequent and serious condition with almost $50 \%$ of in-hospital mortality despite the therapeutic advances.
\end{abstract}

DESCRIPTORS: Shock, cardiogenic. Myocardial infarction. Percutaneous coronary intervention. Inta-aortic balloon pumping.
RESUMO

\author{
Evolução Hospitalar de Pacientes com Choque \\ Cardiogênico por Infarto Agudo do Miocárdio com \\ Supradesnivelamento do Segmento ST
}

Introdução: O choque cardiogênico é uma condição clínica de inadequada perfusão tecidual devido à disfunção cardíaca. A etiologia mais comum é o infarto agudo do miocárdio com elevação do segmento ST (IMCSST) levando à insuficiência ventricular esquerda, mas também pode ser causado por complicações mecânicas, como insuficiência mitral aguda, ruptura do septo interventricular ou da parede livre do ventrículo esquerdo. Apesar dos avanços terapêuticos, a mortalidade continua elevada. Métodos: Estudo retrospectivo, observacional, unicêntrico, incluindo pacientes consecutivos internados com o diagnóstico de IMCSST e choque cardiogênico, tratados por intervenção coronária percutânea (ICP), em hospital terciário especializado em cardiologia. O objetivo primário foi avaliar os desfechos clínicos hospitalares. Resultados: Foram incluídos 78 pacientes, a maioria do sexo masculino $(67,9 \%)$, com idade de $67,5 \pm 13,4$ anos e $41,0 \%$ diabéticos. ICP primária foi realizada em $46,2 \%$ dos pacientes, ICP de resgate em $25,6 \%$ e ICP eletiva em $28,2 \%$ dos casos. As artérias mais frequentemente acometidas foram a descendente anterior e a coronária direita, com $44,9 \%$ cada uma. O balão intra-aórtico foi utilizado em $32,1 \%$ e os inibidores da glicoproteína llb/ IIla em 30,8\% dos casos. A incidência de insuficiência renal aguda foi de $61,5 \%$. A necessidade de reintervenção ocorreu em $9,0 \%$, e a taxa de trombose aguda/subaguda foi de $3,8 \%$. Óbito, no choque cardiogênico, ocorreu em $46,2 \%$. Conclusões: $\mathrm{O}$ choque cardiogênico permanece uma entidade frequente e grave, com quase $50 \%$ de mortalidade hospitalar, apesar da evolução na terapêutica instituída atualmente.

DESCRITORES: Choque cardiogênico. Infarto do miocárdio. Intervenção coronária percutânea. Balão intra-aórtico.

\footnotetext{
1 Interventionist Cardiologist Physician at Instituto do Coração do Hospital das Clínicas da Faculdade de Medicina da Universidade de São Paulo, São Paulo, SP, Brazil.

2 Interventionist Cardiologist Physician at Instituto do Coração do Hospital das Clínicas da Faculdade de Medicina da Universidade de São Paulo, São Paulo, SP, Brazil.

3 Interventionist Cardiologist Physician at Instituto do Coração do Hospital das Clínicas da Faculdade de Medicina da Universidade de São Paulo, São Paulo, SP, Brazil.

${ }^{4}$ Interventionist Cardiologist Physician. Assistant at the Interventional Cardiology Service of Instituto do Coração do Hospital das Clínicas da Faculdade de Medicina da Universidade de São Paulo, São Paulo, SP, Brazil.
} ${ }^{5}$ Full professor. Head of the Interventional Cardiology Service of Ins-
tituto do Coração do Hospital das Clínicas da Faculdade de Medicina
da Universidade de São Paulo, São Paulo, SP, Brazil.

Correspondence to: Francisco Hedilberto Feitosa Filho. R. Olímpio Galdino de Sousa, 50 - Gurarapes - Fortaleza, CE, Brazil - CEP 60810-005 E-mail: fhfeitosafilho@yahoo.com.br

Received on: 6/7/2013 • Accepted on: 8/27/2013 
C ardiogenic shock is a clinical condition of inadequate tissue perfusion due to cardiac dysfunction. Its definition includes the following hemodynamic parameters: persistent hypotension (systolic pressure $<80$ to $90 \mathrm{mmHg}$ or mean blood pressure $30 \mathrm{mmHg}$ lower than mean baseline blood pressure), with a marked reduction in cardiac index $\left(<1.8 \mathrm{~L} / \mathrm{min}\right.$ per $\mathrm{m}^{2}$, without hemodynamic support, or $<2.0$ to $2.2 \mathrm{~L} / \mathrm{min}$ per $\mathrm{m}^{2}$ with hemodynamic support) and normal or elevated ventricular filling pressures. The most common etiology of cardiogenic shock isST-segment elevation myocardial infarction (STEMI), leading to left ventricular failure, but it can also be caused by mechanical complications, such as acute mitral regurgitation, or rupture of the interventricular septum or left ventricular free wall. However, any cause of severe acute ventricular dysfunction, either right or left, can lead to cardiogenic shock. ${ }^{1}$

The prevalence of cardiogenic shock appears to be decreasing since the mid-1970s. In a report from a metropolitan area in the United States (Worcester, Massachusetts), the incidence of cardiogenic shock was $7 \%$ between 1975 and 1990, decreasing to $5.5 \%$ to $6.0 \%$ since then. ${ }^{2}$ This improvement in the incidence of cardiogenic shock and associated mortality partly reflects the increasein the use of coronary reperfusion strategies, which, through correction of the infarct-related arterial patency, may limit the extentof the infarction..$^{3-5}$

In this context, the mortality rates are still high, ranging in the most recent studies from $42 \%$ to $48 \% .^{2,6,7}$ Temporal analysis demonstrated a reduction in this outcome between the years 1995 and 2004 (60.3\%vs. 47.9\%; $\mathrm{P}<0.001)$, mainly associated with the performance of early percutaneous coronary intervention $(\mathrm{PCl})$, with the most evident benefit during the in-hospital period. ${ }^{2}$ This concept is important because, although studies have shown no differences between the mortality rates in relation to the chosen method of revascularization, ${ }^{8}$ in clinical practice more than $60 \%$ of patients admitted with STEMI and cardiogenic shock are treated by early $\mathrm{PCl}$, with emergency coronary artery bypass graft (CABG) surgery performed in less than $5 \%$ of cases.

There have been few studies carried out in the Brazilian population admitted with STEMI, and the data related to cardiogenic shock were obtained from small subgroups. ${ }^{8-11}$ Thus, the present work aimed to evaluate the short-term hospital evolution and outcomes of these patients, treated in a tertiary hospital specialized in cardiology.

\section{METHODS}

\section{Study Population}

This study evaluated patients with STEMI who underwent $\mathrm{PCl}$ at Instituto do Coração do Hospital das Clínicas da Faculdade de Medicina da Universidade de
São Paulo (Incor/HCFMUSP) in São Paulo, SP, Brazil, from January 2008 to March 2011. This study included all patients who developed cardiogenic shock during hospitalization and who were treated by $\mathrm{PCl}$ (primary, rescue, or elective).

\section{Data collection and analysis}

The in-hospital evolution data were collected by trained physicians, during the index hospitalization, following the completion of previously standardized forms. The data collected included clinical features, laboratory test results, percutaneous procedure data, and clinical outcome until hospital discharge.

\section{Definitions}

STEMI was diagnosed upon the occurrence of persistent ST elevation $>1 \mathrm{~mm}$ in two contiguous leads or new left bundle branch block inthe electrocardiogram. Cardiogenic shock was defined by clinical criteria, according to the Should We Emergently Revascularize Occluded Coronaries for Cardiogenic Shock (SHOCK) trial, considering the presence of hypotension (systolic blood pressure $<90 \mathrm{mmHg}$ for at least 30 minutes or requiring supportive measures to maintain systolic blood pressure $>90 \mathrm{mmHg}$ ) and organic hypoperfusion (urine output $<30 \mathrm{~mL} /$ minute and heart rate $>60 \mathrm{bpm}){ }^{8}$

Acute renal failure was considered as a $25 \%$ increase in baseline serum creatinine, or absolute increase of $0.5 \mathrm{mg} / \mathrm{dL}$ in serum creatinine between two and seven days after procedure completion. ${ }^{12}$ The evaluated vascular complications were pseudo aneurysm, arteriovenous fistula, hematoma at the access site (> $10 \mathrm{~cm})$, distal embolization and/or ischaemia related to the puncture site, and bleeding at the access site, defined as a decrease in hemoglobin $>2 \mathrm{~g} / \mathrm{dL}$ or one requiring transfusion. Death was defined as death from any cause. ${ }^{11}$

Continuous variables were represented as means and standard deviations, and categorical variables as absolute numbers and percentages.

\section{RESULTS}

Of a total of 513 patients diagnosed with STEMI, $78(15.2 \%)$ had cardiogenic shock. The clinical characteristics of the included patients are summarized in Table 1 . The majority were male $(67.9 \%)$ with mean age of $67.5 \pm 13.4$ years. Diabetes was present in $41.0 \%$ of patients and $9 \%$ used insulin. Prior $\mathrm{PCl}$ had been performed in $16.7 \%$ of patients and $7.7 \%$ had undergone previous CABG. Chronic renal failure and peripheral vascular insufficiency were present in $15.4 \%$ and $10.3 \%$ of patients, respectively.

Regarding the reperfusion therapy, $46.2 \%$ of patients underwent primary, $25.6 \%$ rescue, and $28.2 \%$ elective $\mathrm{PCl}$. Left anterior descending artery and right coronary 
TABLE 1

Clinical, angiographic and procedural characteristics

\begin{tabular}{|c|c|}
\hline Characteristics & $n=78$ \\
\hline Age, years & $64.5 \pm 13.4$ \\
\hline Male gender, n (\%) & $53(67.9)$ \\
\hline Arterial hypertension, $\mathrm{n}(\%)$ & $65(83.3)$ \\
\hline Dyslipidemia, n (\%) & 67 (85.9) \\
\hline Statin use & $44(56.4)$ \\
\hline Diabetes mellitus, n (\%) & $32(41.0)$ \\
\hline Insulin use & $7(9.0)$ \\
\hline \multicolumn{2}{|l|}{ Smoking, n (\%) } \\
\hline Never & $30(38.5)$ \\
\hline Stopped $<1$ year & $2(2.5)$ \\
\hline Stopped > 1 year & $14(17.9)$ \\
\hline Current smoker & $32(41.0)$ \\
\hline Family history of CAD, n (\%) & $12(15.4)$ \\
\hline Previous stroke, n (\%) & $3(3.9)$ \\
\hline Previous $\mathrm{PCl}, \mathrm{n}(\%)$ & $13(16.7)$ \\
\hline Previous CABG, n (\%) & $6(7.7)$ \\
\hline COPD, n (\%) & $6(7.7)$ \\
\hline Hypothyroidism, n (\%) & $4(5.1)$ \\
\hline Chronic renal failure, n (\%) & $12(15.4)$ \\
\hline Renal transplantation, n (\%) & $1(1.3)$ \\
\hline Peripheral vascular failure, n (\%) & $8(10.3)$ \\
\hline Congestive heart failure, n (\%) & $18(23.1)$ \\
\hline Cocaine use, n (\%) & $1(1.3)$ \\
\hline Primary $\mathrm{PCl}, \mathrm{n}(\%)$ & $36(46.2)$ \\
\hline Rescue PCI, n (\%) & $20(25.6)$ \\
\hline Elective PCI, n (\%) & $22(28.2)$ \\
\hline \multicolumn{2}{|l|}{ Infarct location, n (\%) } \\
\hline Anterior & $35(44.9)$ \\
\hline Inferior + right ventricle & $2(2.6)$ \\
\hline Inferior & $35(44.9)$ \\
\hline Inferodorsal & $3(3.8)$ \\
\hline Lateral & $2(2.6)$ \\
\hline Laterodorsal & $1(1.3)$ \\
\hline \multicolumn{2}{|l|}{ Culprit artery, n (\%) } \\
\hline Left anterior descending artery & $35(44.9)$ \\
\hline Left circumflex artery & $8(10.2)$ \\
\hline Right coronary & $35(44.9)$ \\
\hline Intra-aortic balloon use, n (\%) & $25(32.1)$ \\
\hline GPI IIb/IIla use, n (\%) & $24(30.8)$ \\
\hline
\end{tabular}

$\mathrm{CAD}=$ coronary artery disease $\mathrm{PCl}=$ percutaneous coronary intervention; $\mathrm{CABG}=$ coronary-artery bypass grafting; $\mathrm{COPD}$ = chronic obstructive pulmonary disease; $\mathrm{GPI}=$ glycoprotein inhibitors. arteries were each the culprit arteries of STEMI in 44.9 $\%$ of patients. The intra-aortic balloon was used in $32.1 \%$ of cases, and glycoprotein Ilb/IIla inhibitors in $30.8 \%$ of cases.

Clinical outcomes and in-hospital complications are shown in Table 2. The main complication associated with cardiogenic shock was the development of acute renal failure, which occurred in $61.5 \%$ of cases. The need for re-intervention occurred in $9.0 \%$ of the cases and the rate of acute/subacute thrombosis was $3.8 \%$. The death rate from cardiogenic shock was $46.2 \%$.

\section{DISCUSSION}

Cardiogenic shock is the leading cause of death for patients admitted with STEMI and, despite treatment advances in recent years, including early revascularization through $\mathrm{PCl}$ or $\mathrm{CABG}$, as well as the use of potent anticoagulant and antiplatelet agents, the mortality rates remain high.

Despite the high mortality rate observed in this study, it is very close to that reported in the literature, described as between $42 \%$ and $65 \%$ of patients, especially when the intra-aortic balloon was indicated during $\mathrm{PCl}$ with established cardiogenic shock. ${ }^{13-15}$ In a sub-analysis of the American National Registry of Myocardial Infarction 2 (NRMI-2), ${ }^{16}$ the mortality rate from AMI complicated by cardiogenic shock, even in hospitals with extensive use of intra-aortic balloon, was $50.6 \%$,versus $65.4 \%$ in hospitals with lower rates of use of this circulatory support device $(P<0.001)$.

The decrease of mortality in cardiogenic shock is related to achieving successful recanalization of the culprit vessel. In the SHOCK trial, ${ }^{8}$ a mortality rate of $39 \%$ was demonstrated in successfully treated cases, and a rate of $85 \%$ in cases thatdid not attain procedural success. All patients with TIMI flow 0 or 1 at the end

TABLE 2

Clinical outcomes and in-hospital complications

\begin{tabular}{lc}
\hline Events & $\mathbf{n}=\mathbf{7 8}$ \\
\hline Death, n (\%) & $36(46.2)$ \\
Stroke, n (\%) & $1(1.3)$ \\
Re-intervention, n (\%) & $7(9.0)$ \\
Acute/subacute stent thrombosis, n (\%) & $3(3.8)$ \\
Bleeding, n (\%) & $4(5.1)$ \\
Blood transfusion, n (\%) & $7(9.0)$ \\
Acute pulmonary oedema, n (\%) & $33(42.3)$ \\
Vascular surgery, n (\%) & $1(1.3)$ \\
Acute renal failure, n (\%) & $48(61.5)$ \\
Hemodialysis, n (\%) & $12(15.4)$ \\
\hline
\end{tabular}


of the intervention progressed to death. In the late sixyear follow-up, the early reperfusion strategy showed a relative reduction in mortality of $67 \%$, in comparison with the initial clinical compensation strategy. ${ }^{12}$ Another recent clinical trial, comparing mortality throughout 35 years of evolution of cardiogenic shock treatment, showed a significant reduction in mortality rates overtime $(76 \%$ in $1980 \mathrm{~s}, 65.6 \%$ in the $1990 \mathrm{~s}$, and $42 \%$ since 2000), which are similar values to those found in this study's population. ${ }^{17}$

\section{Study limitations}

Among the limitations of the present study are its observational design and lack of control group. The lack of appropriate time of ischaemia assessment is also highlighted. This was due to the fact that many patients were transferred directly from other peripheral healthcare network services to undergo $\mathrm{PCl}$, which limited the appropriate evaluation of the pain-to-door and door-to-balloon time, once the data were obtained from medical records and, in many cases, this information was not obtained. These pain-to-door and door-to-balloon time variables could provide further information, as both were significantly correlated with the mortality rate in the literature. . $^{8,18,19}$

\section{CONCLUSIONS}

Cardiogenic shock remains a frequent and severe entity, with mortality rates of approximately $50 \%$ despite the currently established therapy. Therefore, it is observed that the best strategy would be the prevention of acute coronary events and, when they occur, early myocardial reperfusion measures should be attempted to prevent circulatory collapse and its unfavorable consequences.

\section{CONFLICTS OF INTEREST}

The authors declare no conflicts of interest.

\section{REFERENCES}

1. Reynolds HR, Hochman JS. Cardiogenic shock: current concepts and improving outcomes. Circulation. 2008;117(5):686-97.

2. Babaev A, Frederick PD, Pasta DJ, Every N, Sichrovsky T, Hochman JS; NRMI Investigators. Trends in management and outcomes of patients with acute myocardial infarction complicated by cardiogenic shock. JAMA. 2005;294(4):448-54.

3. Goldberg RJ, Gore JM, Thompson CA, Gurwitz JH. Recent magnitude of and temporal trends (1994-1997) in the incidence and hospital death rates of cardiogenic shock complicating acute myocardial infarction: the second national registry of myocardial infarction. Am Heart J. 2001;141(1):65-72.

4. Goldberg RJ, Samad NA, Yarzebski J, Gurwitz J, Bigelow C, Gore JM. Temporal trends in cardiogenic shock complicating acute myocardial infarction. N Engl J Med. 1999;340(15): 1162-8.

5. Meinertz T, Kasper W, Schumacher M, Just H. The German multicenter trial of anisoylated plasminogen streptokinase activator complex versus heparin for acute myocardial infarction. Am J Cardiol. 1988;62(7):347-51.

6. Alexander JH, Reynolds HR, Stebbins AL, Dzavik V, Harrington RA, Van de Werf $F$, et al. Effect of tilarginine acetate in patients with acute myocardial infarction and cardiogenic shock: the TRIUMPH randomized controlled trial. JAMA. 2007;297(15):1657-66.

7. Campos CAHM, Ribeiro HB, Ribeiro EE, Spadaro AG, Lemos PA, Perin $M$, et al. Caracterização e impacto clínico tardio do noreflow associado a intervenção coronária percutânea primária vs. eletiva. Rev Bras Cardiol Invasiva. 2010;18(3):300-5.

8. White HD, Assmann SF, Sanborn TA, Jacobs AK, Webb JG, Sleeper LA, et al. Comparison of percutaneous coronary intervention and coronary artery bypass grafting after acute myocardial infarction complicated by cardiogenic shock: results from the Should We Emergently Revascularize Occluded Coronaries for Cardiogenic Shock (SHOCK) trial. Circulation. 2005;112(13):1992-2001.

9. Nicolau JC, Serrano CV Jr, Garzon SA, Ramires JA. Prognosis of acute myocardial infarction in the thrombolytic era: medical evaluation is still valuable. Eur J Heart Fail. 2001; 3(5):569-76.

10. Valim LR, Lopes ACA, Bienert IRC, Ribeiro HB, Campos CA, Esper RB, et al. Infarto agudo do miocárdio complicado por choque cardiogênico: efeito da circulação colateral nos resultados da intervenção coronária percutânea primária - Dados do Registro InCor. Rev Bras Cardiol Invasiva. 2011;19(2):166-71.

11. Conejo F, Santos LN, Ribeiro HB, Campos CA, Pozetti AH, Lopes Jr. AC, et al. Evolução hospitalar de pacientes submetidos a assistência circulatória com balão intra-aórtico durante intervenção coronária percutânea de alto risco: Registro InCor. Ver Bras Cardiol Invasiva. 2011;19(4):392-9.

12. Hochman JS, Sleeper LA, Webb JG, Dzavik V, Buller CE, Aylward $\mathrm{P}$, et al. Early revascularization and long-term survival in cardiogenic shock complicating acute myocardial infarction. JAMA. 2006;295(21):2511-5.

13. Abdel-Wahab M, Saad M, Kynast J, Geist V, Sherif MA, Richardt G, et al. Comparison of hospital mortality with intraaortic balloon counterpulsation insertion before versus after primary percutaneous coronary intervention for cardiogenic shock complicating acute myocardial infarction. Am J Cardiol. 2010;105(7):967-71.

14. Barron HV, Every NR, Parsons LS, Angeja B, Goldberg RJ, Gore JM, et al. The use of intra-aortic balloon counterpulsation in patients with cardiogenic shock complicating acute myocardial infarction: data from the National Registry of Myocardial Infarction 2. Am Heart J. 2001;141(6):933-9.

15. Cheng JM, Valk SD, den Uil CA, van der Ent M, Lagrand WK van de Sande $M$, et al. Usefulness of intra-aortic balloon pump counterpulsation in patients with cardiogenic shock from acute myocardial infarction. Am J Cardiol. 2009;104(3):327-32.

16. Chen EW, Canto JG, Parsons LS, Peterson ED, Littrell KA, Every NR, et al. Relation between hospital intra-aortic balloon counterpulsation volume and mortality in acute myocardial infarction complicated by cardiogenic shock. Circulation. 2003; 108(8):951-7.

17. Goldberg RJ, Spencer FA, Gore JM, Lessard D, Yarzebski J. Thirty-year trends (1975 to 2005) in the magnitude of, management of, and hospital death rates associated with cardiogenic 
shock in patients with acute myocardial infarction: a population based perspective. Circulation. 2009;119(9):1211-9.

18. Sanborn TA, Sleeper LA, Webb JG, French JK, Bergman G, Parikh $\mathrm{M}$, et al. Correlates of one-year survival inpatients with cardiogenic shock complicating acute myocardial infarction: angiographic findings from the SHOCK trial. J Am Coll Cardiol. 2003;42(8):1373-9.
19. Wong SC, Sanborn T, Sleeper LA, Webb JG, Pilchik R, Hart D, et al. Angiographic findings and clinical correlates in patients with cardiogenic shock complicating acute myocardial infarction: a report from the SHOCK Trial Registry. SHould we emergently revascularize Occluded Coronaries for cardiogenic shock? J Am Coll Cardiol. 2000;36(3 Suppl A): 1077-83. 